\title{
Pertunjukan Jonggan Dalam Konteks Sosial Kemasyarakatan Suku Dayak Kanayatn
}

\author{
Turyati \\ Institut Seni Budaya Indonesia (ISBI) Bandung \\ Jln. Buah Batu 212 Bandung
}

\begin{abstract}
Jonggan is a traditional dancing performance of the people of Dayak Kanayatn tribe. This dance is performed to welcome honorable guests. Jongan performance is related to various ritual ceremonies and social ceremonies, such as Naik Dango (crop harvesting ceremony), marriage, Gawai Dayak (folk festival). This dance is generally performed by elders and young people, men and women, however mostly old people perform it as it serves old poems that consist of advice, moral, religious value and life guidance. This Jonggan investigation uses ethnographic approach to record esthetics behavior and social cultural behavior in the performance of Jongan. The result of the research indicates that young people tend to dance in couple to build communication in the Jonggan event rather than responding and giving poems. Emotional touches, joy occurs as an expression of unity, personal, and communal that give real image of a relationship that develop between personal emotions. The symptom of the performance indicates the occurrence of interaction and social integration that leads to the construction of community social cohesion.
\end{abstract}

Keywords: Jonggan, Dayak Kanayatn, dance performance

\begin{abstract}
ABSTRAK
Jonggan merupakan pertunjukan tari tradisi masyarakat suku Dayak Kanayatn. Tarian ini disajikan untuk penyambutan tamu terhormat. Pertunjukan Jonggan terkait dengan berbagai hajat ritual dan hajat sosial masyarakat, antara lain Naik Dango (Ritual panen padi), perkawinan, dan Gawai Dayak (pesta rakyat). Tarian ini biasa ditarikan oleh kaum tua dan muda, laki-laki dan perempuan, tetapi biasanya dihadiri oleh sebagian besar orang tua, karena di dalamnya disajikan pantun-pantun lama yang berisi petuah, moral, agama, dan pandangan hidup. Penelitian Jonggan ini menggunakan pendekatan etnografi untuk mencatat perilaku estetik dan perilaku sosial budaya dalam pertunjukan Jonggan. Hasil penelitian ini menjelaskan bahwa anak muda lebih suka menari berpasangan untuk membangun komunikasi dalam acara Jonggan dari pada harus berbalas pantun. Sentuhan emosional, kegembiraan muncul sebagai ungkapan kebersamaan, pribadi, dan komunal yang memberikan gambaran nyata dari hubungan yang berkembang antara emosi pribadi. Gejala pertunjukan menunjukkan terjadinya interaksi dan integrasi sosial yang bermuara pada terbangunnya kohesi sosial masyarakat.
\end{abstract}

Kata kunci: Jonggan, Dayak Kanayatn, Pertunjukan, Tari 


\section{PENDAHULUAN}

Jonggan adalah bentuk kesenian khas suku Dayak Kanayatn yang di dalamnya terdiri atas penari, pemusik, dan juga penyanyi. Lebih tepatnya kesenian ini biasa disebut sebagai tari pergaulan masyarakat suku Dayak Kanayatn, yang terletak di desa Sekabuk kecamatan Sadaniang Kabupaten Pontianak Kalimantan Barat.

Masyarakat setempat mengatakan Jonggan adalah pertunjukan yang dilakukan masyarakat sebagai tradisi leluhur suku Dayak Kanayatn yang biasanya dipertunjukkan untuk menyambut para tamu agung atau tamu yang dihormati yang statusnya lebih tinggi dari mereka (Bihen, wawancara 5 Pebruari 2009). Kesenian ini bisa ditarikan oleh tua muda laki-laki dan perempuan, meskipun yang seringkali hadir adalah kalangan tua. Dalam pertunjukan Jonggan terdapat nyanyian yang berupa sajian pantun yang biasanya dilakukan secara berkelompok dan beberapa dari penonton dapat ikut menari. Tarian ini akan lebih ramai atau hidup jika terjadi saling berbalas pantun antara penonton yang menari dalam kelompok atau grup Jonggan.

Tradisi Jonggan memberikan gambaran kekuatan integritas sosial warga desa Sekabuk, sebagai media integrasi warga yang secara lokasi tinggal di wilayah yang sangat membutuhkan kerukunan sosial dalam hidup sehari-hari. Masyarakat suku Dayak Kanayatn yang tinggal di wilayah ini bermatapencaharian utama berladang dan mencari hasil hutan. Sebagian kecil berdagang dan ada juga yang menjadi pegawai negeri yaitu sebagai guru di sekolahsekolah di mana dia bertempat tinggal. Desa Sekabuk masih terpencil dan terbelakang, karena daerah ini sangat jauh dari ibukota Provinsi Pontianak.
Masyarakat belum dapat bepergian jauh ke luar wilayahnya karena keterbatasan sarana transportasi yang hanya ada pada waktu pagi hari untuk membawa penumpang yang akan berbelanja kebutuhan sehari-hari, atau pergi untuk urusan lainnya. Kendaraan baru kembali pada sore harinya untuk membawa penumpang kembali ke desa Sekabuk. Mobil atau kendaraan yang digunakan sebagai sarana angkutan umum berupa angkutan pedesaan sudah sangat tua umurnya. Bagi mereka yang mempunyai sepeda motor biasanya dapat bepergian secara bebas, sepeda motor dipandang sebagai sarana transportasi yang efektif.

Perempuan Dayak di pedesaan dikenal dengan pekerja yang tak kenal lelah, dari mulai mengurus anak, mengurus rumah, pergi ke ladang/sawah, menganyam, sampai dengan menoreh karet, dan lainlain. Ada ketidakjelasan pembagian kerja antara kelompok laki-laki dan perempuan, yang akhirnya perempuan banyak mendominasi pekerjaan di ladang/sawah sehingga adanya pergeseran tanggung jawab peranan suami sebagai tulang punggung keluarga kepada kelompok perempuan (Julipin, 2011: 116). Menjadi pemandangan yang sudah umum bagi perempuan suku Dayak Kanayatn yang berada di pedesaan, bahwa alat pikul yang disebut jare/tingkalakng/kataro selalu berada di punggung para perempuan apabila mereka pergi ke ladang/sawah, yang sebenarnya kelompok laki-laki bisa juga menggunakannya (2011: 117).

Perempuan suku Dayak Kanayatn di Sekabuk yang sudah tidak bersekolah, mereka yang sudah menikah kemudian noreh (menoreh pohon karet) ke hutan. Para perempuan Dayak juga terkenal ulet dalam bekerja di ladang menanam padi huma yaitu 
cara menanam padi di ladang atau di hutan tanpa membutuhkan genangan air.

Kaum laki-laki biasa berburu ke hutan pada malam hari untuk mencari binatang buruan atau hasil hutan lainnya. Mereka pulang menjelang pagi. Hasil yang didapat dijual untuk mencukupi kebutuhan seharihari. Masyarakat luar pada umumnya menilai bahwa perempuan suku Dayak adalah pekerja keras, lebih rajin, lebih ulet, dan sangat hormat atau patuh pada suami/ kaum laki-laki.

Sistem pergaulan masyarakat desa Sekabuk berbeda dengan pergaulan masyarakat kota. Keterbatasan lingkungan pedesaan mendorong tradisi bergaul dalam ruang alami, pada sore hari anak-anak muda bermain sepakbola, bergerombol di tempat strategis di ujung jalan. Beberapa di antara mereka sibuk mencari sinyal telepon selulernya di pinggiran desa, karena di desa ini sinyal memang susah dijangkau oleh jaringan komunikasi melalui telepon gengam. Handphone jarang bisa aktif kecuali di tempat-tempat tertentu, seperti misalnya di tempat yang agak tinggi atau tempat lain di mana sinyal yang dibutuhkan dapat tertangkap dengan baik.

Setelah malam suasana menjadi sepi, setelah seharian bekerja di hutan warga kebanyakan dari mereka beristirahat di dalam rumah sambil menonton televisi. Televisi menjadi salah satu media hiburan bagi masyarakat. Bagi yang belum memiliki televisi biasanya berkumpul menonton televisi di rumah tetangga sambil bersenda-gurau, saling menceriterakan pengalaman sehari-hari. Komunikasi sosial antar warga desa diwarnai oleh keramahtamahan yang dapat diamati dari tegur sapanya ketika bertemu di jalan, atau di warung ketika berbelanja. Solidaritas sosial, ikatan emosional yang pekat pada ruang-ruang pertemuan sosial menjadikan integritas sosial masyarakat semakin kokoh.

Kehadiran orang baru, tamu dari luar daerah cepat dikenali, bahkan kehadiran orang baru yang sama sekali belum dikenal menimbulkan jarak sosial. Rasa ingin tahu, curiga, kepekaan sosial ini semakin tajam apabila tamu atau orang baru membawa peralatan rekam (camera, handycame) selalu dianggap sebagai awal penyiaran televisi.

Suasana pedesaan merupakan lingkungan alam yang masih murni, jauh dari keramaian kota sehingga desa tetap tenang damai, bahkan cenderung sangat sepi. Tidak ada suasana bising yang bersumber pada mesin mobil ataupun kendaraan bermotor. Hanya sekali-sekali terdengr motor melintasi desa. Alat transportasi yaitu angkutan pedesaan lewat hanya satu kali dalam sehari, yaitu yang berangkat menuju kota kecamatan dan yang pulang lagi ke tempat awal. Bagi masyarakat yang ingin bepergian sewaktuwaktu bisa menggunakan sepeda motor yang dimilikinya.

Rumah-rumah pemukiman memiliki jarak yang cukup jauh, tidak terlalu rapat antara rumah satu dan rumah yang lainnya. Lahan tanah di desa ini masih luas dan masih bisa dibangun rumah-rumah baru. Dataran tanah yang berbukit-bukit membuat pemukiman di sekitar desa ini berkelompok-kelompok, dan di sekitar rumah masih bisa ditanami padi, pisang, ubi jalar, dan palawija lainnya.

\section{METODE}

Penelitian ini lebih berorentasi pada pendekatan etnografi mengenai peristiwa pertunjukan Jonggan dalam kehidupan masyarakat penuturnya dan mencoba mendeskripsikan peristiwa natural pertunjukan Jonggan sebagaimana dialami dan dihayati oleh penuturnya. Melihat fakta ter- 
sebut dirasakan perlu penulisan tentang pertunjukan Jonggan dalam kehidupan masyarakat suku Dayak Kanayatn. Penulisan tersebut diharapkan dapat menjadi informasi awal yang menawarkan penelitian lanjutan.

Untuk itu dilakukan pengamatan terhadap kehidupan masyarakat, struktur pertunjukan, wawancara pada pelaku pertunjukan untuk mendapatkan data sebanyak mungkin. Selanjutnya data dideskripsikan berdasarkan struktur peristiwa sosial budaya sebagaimana dialami oleh penulis bersama dengan masyarakat penuturnya.

\section{HASIL DAN PEMBAHASAN}

\section{Pra-pertunjukan Jonggan}

Persiapan pokok pertunjukan Jonggan berkenaan dengan penyiapan panggung. Panggung dibuat mirip sebuah rumah panggung sederhana berbentuk empat persegi panjang berukuran $6 \times 12 \mathrm{~m}$ lantai terbuat dari papan yang ditata. Lantai setinggi $75 \mathrm{~cm}$ dari permukaan tanah, pada bagian atas dipasang kain terpal sebagai atap yang melindungi panggung dari guyuran air hujan atau panas matahari.

Pada lantai panggung bagian depan, samping kanan kiri dipasang anak tangga sebagai alat untuk naik ke atas panggung. Tangga terbuat dari kayu yang dipasang kuat sehingga dapat menerima beban tubuh penari yang naik ke atas lantai panggung. Lantai panggung berupa hamparan papan kayu yang dipasang secara kuat pada bidang persegi empat yang terbuat dari kayu relevan dengan bangun panggungnya.

Pada setiap sisi panggung bagian atas dipasang daun kelapa terjuntai ke bawah sehingga menyerupai rumbairumbai. Pada bagian panggung paling belakang dibentangkan spanduk bertuliskan nama grup Jonggan daerah asalnya.
Pada bagian atas pentas digantungkan beberapa lampu sebagai penerang ruangan panggung yang dibagi menjadi tiga bagian terdiri atas bagian yang digunakan tempat alat musik dan pemain musik, tempat sound sistem, dan area pentas tari.

Di belakang rumah kaum perempuannya sibuk menyiapkan berbagai makanan yang akan dihidangkan dalam perjamuan. Beberapa kelompok laki-laki telah menyembelih babi, dan kemudian memasaknya sampai dengan siap untuk dihidangkan dalam perjamuan. Di ruang depan beberapa kelompok wanita muda dan laki-laki menyiapkan tempat duduk pengantin dengan berbagai penghias ruangan serta menyiapkan ruang makan dan tempat duduk tamu undangan. Di bagian belakang panggung para penari telah mempersiapkan dirinya dengan mengenakan kostum yang terdiri atas kebaya dan kain. Penarinya adalah gadis muda yang berumur kira-kira 14 sampai 15 tahun yang rata-rata duduk di Sekolah Menengah Pertama (SMP). Mereka berdandan sangat sederhana tanpa polesan makeup, rambutnya diurai apa adanya rambut masing-masing. Para penari mengenakan selendang yang diselempangkan. Seorang penyanyi mengenakan kostum adat Dayak, yang dipenuhi ragam rias dari borci yang gemerlap.

\section{Inti Pertunjukan}

Pertunjukan diawali dengan pembacaan mantra dan pemberian jimat kepada penari Jonggan oleh seorang dukun. Dukun membacakan mantra sambil membakar dupa. Para penari duduk bersimpuh mengelilingi dukun yang membacakan mantra keselamatan dan tolak bala. Setelah pembacaan mantra selesai, sang dukun memberikan beberapa butir beras kepada para penari Jonggan yang diambil dari 


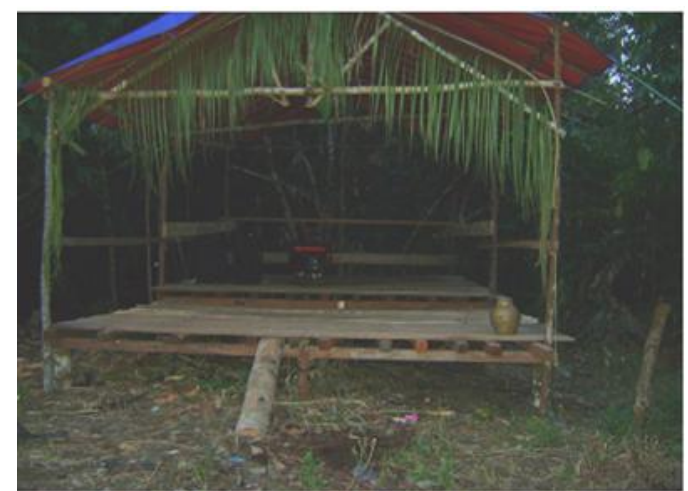

Gambar 1. Panggung Pertunjukan (Foto: Turyati, 2009)

sesajen yang kemudian dimakannya langsung; tujuannya agar terhindar dari gangguan makhluk halus.

Ungkapan-ungkapan dalam vokal mantra atau vokal yang dibawakan dalam ansambel Jonggan dan upacara ritual yang syarat makna ditonjolkan oleh seorang penyanyi yang memang seorang yang lebih tua dari para penarinya. Ungkapan yang disampaikan adalah sebuah rekaman historis kehidupan masyarakat dan tentang asal kesenian itu dilahirkan. Irama musik Dayak Kanayatn sebagai seni tradisi adalah rekaman historis yang dapat dijadikan sebuah kerangka nilai estetis untuk dihayati dalam kehidupan masyarakat pendukungnya. Di samping itu kandungan nilai estetis tersebut dapat pula memberi rasa nikmat, indah, tenteram, damai, menyenangkan, sebagaimana keindahan musik ditampilkan sebagai sajian yang menarik, menyentuh, dan menggetarkan jiwa.

Setelah ritual ini selesai penyanyi Jonggan melantunkan lagu pembuka. Syairnya berisi tentang pengenalan dan pujian kelompok Jonggan yang tampil dalam acara tersebut. Para penari perempuan mulai menari. Mereka mengenakan kebaya dan kain semacam blus panjang dengan selendang panjangnya yang disampirkan di bahu mereka. Rambut dibiarkan terurai. Para penari Jonggan itu mulai melangkahkan kaki dan menggerakkan tubuh mereka.

Mereka melangkahkan kaki ke kanan ke kiri diikuti dengan ayunan tubuh, lengan dan tangan mereka melambai searah gerakan tubuh mereka. Penari berdiri berjajar menghadap ke penonton. Tarian ini merupakan tarian pembuka yang memiliki kesan energik. Penari bergerak dalam irama gerak dan musik yang dinamis walau musik yang dimainkan memiliki pola monoton.

Posisi penari pada bagian awal semuanya menghadap penonton berdiri berjajar. Di belakang berjajar pemain musik, penyanyi, dan pembawa acara yang menghantar dan mengatur pertunjukan Jonggan dari awal sampai akhir. Pada bagian ini ditampilkan seluruh wajah pemain untuk dikenali penonton, ini dirasakan penting sebagai awalan untuk membangun sebuah entitas struktur pertunjukannya. Seluruh komponen pertunjukan dirangsang untuk membangun partisipasi sosial dalam konteks pertunjukan. Setiap penari dapat secara leluasa berkomunikasi dengan pasangan menari, maupun pelaku pertunjukan yang ada di atas pentas. Sentuhan emosional juga kegembiraan yang muncul sebagai ekspresi personal maupun komunal memberikan gambaran konkrit kebersamaan serta tumbuhnya ikatan-ikatan emosi antarpersonal. Sebagai tari pergaulan masyarakat suku Dayak Kanayatn tarian ini benar-benar menceritakan suka cita dan kebahagiaan dalam pergaulan muda mudi sku Dayak Kanayatn. Bagi para tamu dan penonton yang ingin menari bersama dengan penari Jonggan, sebelum naik ke panggung terlebih dulu membeli tiket kepada panitia grup Jonggan seharga 


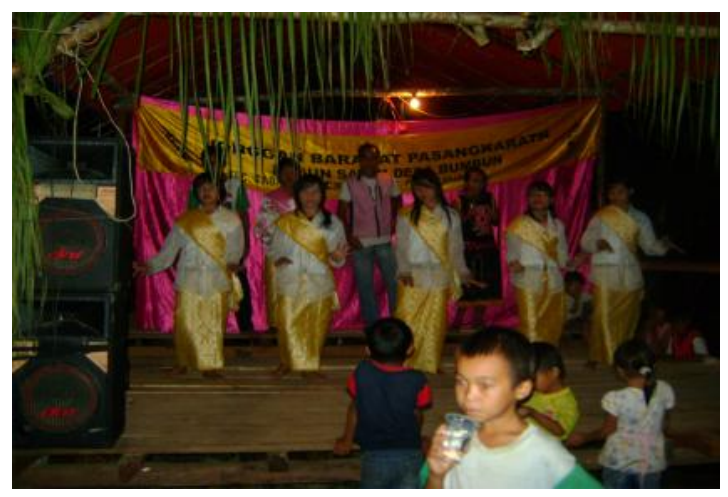

Gambar. 2. Tarian Pembuka (Foto: Turyati, 2009)

25 ribu rupiah perorang untuk satu lagu. Kemudian bagi penonton atau tamu yang sudah membeli tiket tersebut diperkenankan naik ke atas panggung dan memilih penari yang akan diajak menari bersama.

Tarian dimulai dengan gerakan bersama mengayun langkah kaki secara serempak mengikuti irama musik, para penari melenggangkan tangan dengan lambaian gemulai. Gerakan ini dilakukan beberapa saat sampai pada peralihan irama musik seluruh penari mengambil posisi berbanjar saling berhadapan. Para penari laki-laki maupun perempuan mengambil posisi saling perpasangan berhadaphadapan. Posisi berpasangan ini dilakukan dalam beberapa formasi tanpa berganti pasangan. Dapat ditangkap kesan polapola baku dalam menentukan bloking penari sehingga kurang memberikan kemungkinan mengambil gerakan yang memungkinkan untuk mengubah posisi pasangan awalnya.

Para penari sebagian besar adalah kaum muda yang masih lajang dengan sentuhan emosional yang memberikan gambaran integritas komunal yang kuat yang dipandu oleh kesederhanaan tata laku gerak tari dalam membangun ruang komunikasi antara penari satu dan penari yang lainnya tetap dalam formasi formal. Kesan jujur, setia hati, dan bersahaja sangat kuat dalam membangun integritas sosial.

\section{Lagu Syair Jonggan}

\section{Jubata}

Udah Sa'ari, Sa'ari Agi, Nana badiam, Kami bajalan, Takadang jantu, Barang dah latih, Uba'atn barat, Niti maraga, Nang manyak rintangan, Uba'atn barat, Niti maraga, Nang manyak rintangan.

Ka'kita 'Jubata, Kami bapadah, Ka'kita 'Jubata, Kami bapinta, Iring langkah kami, Oh Jubata biar salamatIring langkah kami, Oh Jubata biar salamat

Dangar doaku Jubata, Nang adil, Jauhan kami dari coba'an, Antatlah kami

Man barakat Nyu, Biar kami sampe, Salamat ka'dunia, Salama 'idup, Biar kami sampe, Salamat ka'dunia, Salama idup

Ka'kita 'Jubata, Kami bapadah, Ka'kita 'Jubata, Kami bapinta, Ka'kita 'Jubata, Kami bapadah, Ka'kita 'Jubata, Kami bapinta, Ho...ka'kita 'Jubata, Kami bapadah, Ka'kita 'Jubata, Kami bapinta, Irikng langkah kami, Oh...'Jubata biar salamet, Irikng langkah kami, Oh 'Jubata biar salamat

\section{Daya'ng Male'en}

Udahlah lama, Nana'ka'jabang, Dayang male'ena, Masanga' hormat, Ka'urang' manyak,

Daya'ng male'ena, Kade'lah ada, Jaru'm nang patah, Daya'ng male'ena, Ame disimpan

Ka'dalam pati, Daya'ng male'ena, Kade'lah ada, Pantun nang salah, Daya'ng male'ena, Ame disimpan, Ka'dalam ati, Daya'ng male'ena, Udah lama, Nana' mangebeng, Daya'ng male'ena, Mangebeng tadi, Gi'nape' puas, Daya'ng male'ena 
Kupaslah kupas, Kalapa muda, Daya'ng male'ena, Kalapa tua, Ruang perahu, Daya'ng male'enaPuaslah puas, Badan gi'muda', Daya'ng male'ena, Badan dah tua, Siapa tahu, Daya'ng male'ena

Kacang kacambah, Dari muara, Daya'ng male'ena, Malia' obat, Ka'pasar landak, Daya'ng male'ena

\section{Adi'a}

P: Gule-gule abanga, Ka'pucuk jamu abanga, Ngayapm sueep e'abanga, Ka'tangah uma abanga

P: Mule-mule abanga, Diri' batamu abanga, Amelah supe abanga, Batanya dama abanga

L: Dah lama adi'a, Nana 'ka'amu adi'a, Baru' nian adi'a, Ka' amu agi' adi'a

L: Dah lama adi'a, Nana' batamu adi'a, Barui'nian adi'a, Batamu agi' adi'a

P: dari kantuk abanga, Ka' batu ampar abanga, Aku nana' abanga, Ka'jawa agi'abanga

P: Bumi ditapok abanga, Langit ditamparabanga, Aku nana abanga, Picaya' agi' abanga

L: Kade'lah kao adi'a, Malia' duku adi'a, Aku nian adi'a, Urakng sinakin adi'a

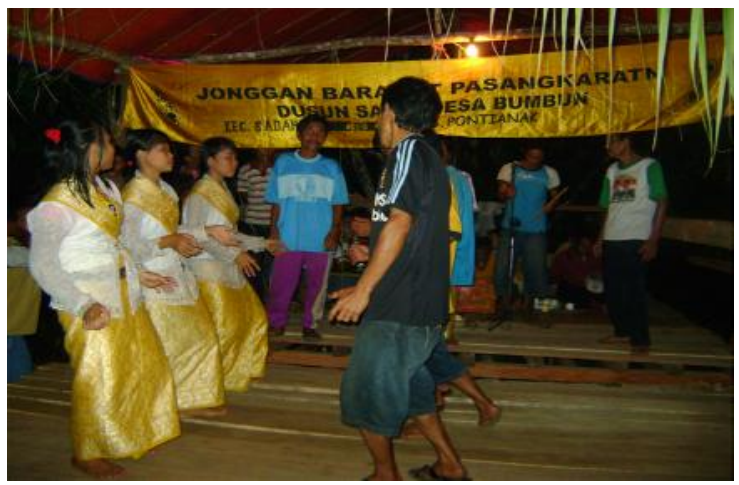

Gambar. 3. Tarian Pasangan

(Foto: Turyati, 2009).
L: Ngahelah kao adi'a, Cinta ka' aku adi'a, Aku nian adi'a, Urakng masikin adi'a

P: Kilamu abanga, $\mathrm{Ka}^{\prime}$ dalapm milik abanga, Jantu malayang abanga, Pangikatnya abanga

P: Biar ilamu abanga, Satinggi langit abanga, Nana' sambayang abanga, Ahe gunaya abanga

Jika didengarkan secara sepintas, musik jonggan mirip dengan jenis-jenis kesenian tradisional lainnya, karena menggunakan alat-alat musik yang hampir sama, yaitu; Agukng (gong), Dau (gamelan), Soleng (seruling) dan Godobokng (gendang). Namun kalau kita telusuri lebih jauh kesenian tradisional Jonggan memiliki ciri yang khas, yang membedakannya dari yang lain.

Permainan musik yang menghantarkan syair-syair yang didendangkan memberikan suasana yang segar semarak. Permainan musik memiliki memiliki elemenelemen dasar meliputi ritme, melodi, dinamika, harmoni, tekstur, bentuk, warna, dan gaya. Ritme dalam musik Jonggan adalah gerakan kehidupan alam. Melodi dalam tradisi musik Jonggan ibarat alur kehidupan yang dijalani masyarakatnya, sedangkan dinamikanya ibarat intensitas kehidupan manusia yang berhubungan dengan konsepsi religius dan adat istiadat. Selanjutnya harmoni dalam irama musik Jonggan merupakan penggabungan konsep hidup secara horizontal yang mengacu pada keserasian hubungan masyarakat dengan lingkungan, para leluhur, makhluk halus, dan Jubata. Melalui penggabungan elemen-elemen tersebut, irama musik Jonggan menjadi sebuah musik yang mempunyai citra keindahan sesuai dengan karakter budayanya. 


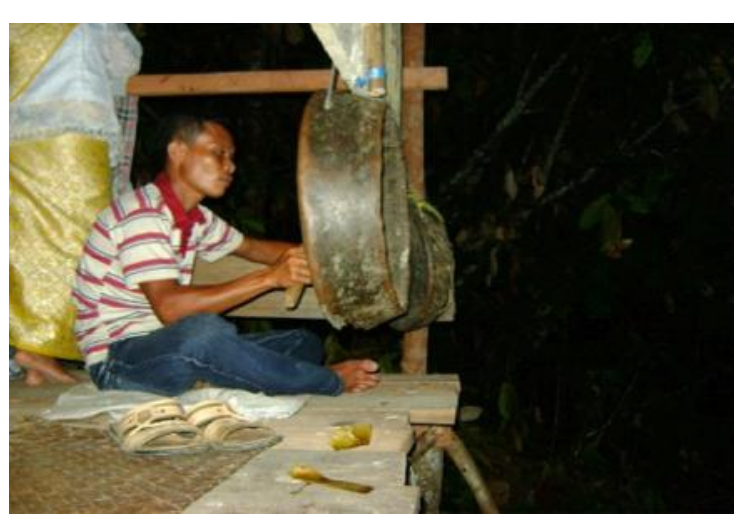

Gambar. 4. Pemain Musik Agukng (Gong) (Foto: Turyati, 2009)

Penyajian irama musik Jonggan mampu memancarkan nilai-nilai estetika yang tidak terlepas dari konsep-konsep musikal dan keindahan. Dalam mengungkapkan nilainilai tersebut, baik nilai simbolis maupun estetis perlu diketahui hubungan konsepnya, bunyi musik, dan perilaku masyarakat dari sebuah budaya musiknya. Keindahan bunyi yang diekspresikan dalam pertunjukan irama musik Jonggan tidak terlepas dari konsep religius, yaitu Tuhan, manusia, dan makhluk gaib (makhluk halus dan roh para leluhur). Dalam kehidupan suku Dayak diyakini bahwa ada tiga dunia, yaitu Dunia Bawah, Dunia Tengah, dan Dunia Atas yang menjadi inspirasi bagi pembentukan nilai-nilai kehidupan.

Dunia Atas dilambangkan dengan Agukng, Dunia Tengah dilambangkan dengan Dau, sedangkan Dunia Bawah dilambangkan dengan Gadobokng. Jalinan ketiga instrumen itu mampu memberikan suatu keindahan dan kesakralan yang dianggap oleh masyarakat sebagai lingkar kehidupan suci dalam dunia ini. Keterampilan dalam menabuh atau memainkan Dau dan instrumen lain membuat musik yang dihasilkan memiliki keserasian. Musik tersebut menjadi sesuatu yang hidup, indah, dan mempunyai keselarasan.
Tiga teknik dalam permainan irama musik Jonggan kebanyakan dikuasai oleh para penyanyi, setidaknya ia mengenal di mana dan kapan ketiga teknik itu dimainkan. Pertunjukan Jonggan mempunyai durasi yang panjang, terkadang dimainkan semalam suntuk. Oleh karena itu setiap pemain harus banyak menguasai pola tabuhan. Para pemain musik sedikitnya harus mengerti keseluruhan lagu yang akan dibawakan dalam upacara tesebut, sehingga bila upacara dimulai para pemain hanya menunggu tanda dari panyampang, selanjutnya mereka memainkan musik dengan sangat akspresif dan bersemangat.

Peresapan yang dalam terlihat ketika salah satu musik dimainkan dan tidak jarang para penonton merasa terpesona menyaksikan penampilan tersebut. Dari sini dapat diketahui bahwa musik juga dapat memberikan sebuah kenikmatan meskipun dimainkan dalam konteks upacara. Unsur kekompakan, kebersatuan, penonjolan, harmoni, serta keanekaragaman atau kompleksitasnya dapat tercapai melaui penangkapan dan pengolahan rasa musikal dari masing-masing pemain, ketrampilan dalam permainan, serta penghayatan yang dalam, yang semuanya dapat memberikan kepuasan tersendiri kepada pelaku dan penikmatnya. Selanjutnya selain lagu dan permainan musik tradisi juga diperdengarkan beberapa musik dan lagu dangdut. Para penari menjadi lebih bersemangat dengan lagu tersebut.

\section{Akhir pertunjukan}

Biasanya setelah pemutaran musik dan lagu dangdut pertunjukan akan segera ditutup. Para penari turun dari panggung saling menyampaikan salam perpisahan, yang ditandai dengan dilantunkannya lagu 
perpisahan. Para penari perempuan akan segera mengganti pakaian pentas mereka dan mengenakan baju harian. Para tamu satu persatu mulai mohon diri dan meninggalkan tempat pertunjukan.

\section{Fungsi Integrasi Sosial Pertunjukan Jonggan}

Kesenian Jonggan dalam kehidupan suku Dayak Kanayatn memiliki fungsi kultural mencakup aktualisasi nilai-nilai kultural yang berkaitan erat dengan nilai kehidupan sosial, nilai estetik kesenian yang dihayati sebagai ekspresi komunal dan individual, serta pencapaian kearifan hidup yang berakar pada kearifan kultural. Pertunjukan Jonggan dalam lingkup budaya adat Dayak Kanayatn merupakan aktivitas sosial budaya yang berkaitan erat dengan tujuan-tujuan sosial. Sebagai peristiwa seni Jonggan dapat dimaknai sebagai peristiwa estetik dan peristiwa sosial budaya.

Hajat kawinan merupakan peristiwa budaya adat yang menghadirkan pertunjukan Jonggan sebagai penyemarak hajatan. Pertunjukannya dalam konteks ini memiliki dampak terbangunnya ruang sosial lewat perjumpaan-perjumpaan warga dalam ruang pertunjukan, yang akhirnya menjadi pusat integrasi antar warga. Proses integrasi didorong oleh motivasi sosial yang berdasar pada adat istiadat dan tradisi luhur warga suku Dayak Kanayatn, yaitu kebersamaan, toleransi sosial, ikatan kekeluargaan, dan gotong royong dalam melaksanakan tugas-tugas sosial kemasyarakatan. Selain itu pertunjukan Jonggan memiliki potensi menumbuhkan ikatansosial yang lebih kuat secara permanen, di mana warga setempat dapat menyatakan perasaan-perasaan sosial melalui bahasa tubuh, pantun, juga beberapa sentuhan emosional yang terjadi pada saat menari berpasangan atau berbalas pantun.
Bentuk toleransinya terungkap lewat partisipasi aktif dalam perilaku warga suku Dayak Kanayatn dalam gotong royong. Partisipasi aktif ini mencerminkan nilai dan sikap rukun yang secara behavioristik diwujudkan secara nyata dalam aktivitas kelompok secara serempak. Spirit untuk saling menolong, bekerja sama tanpa pamrih adalah manifestasi dari sikap rukun. Dalam konteks interaksi sosial hal tersebut merupakan manifestasi kesadaran kolektif untuk tetap membangun integritas individu di tengah-tengah realitas lingkungan dan masyarakat. Secara umum mereka berinteraksi dan berkomunikasi secara luluh dalam peristiwa pertunjukan Jonggan. Kebersamaan, toleransi sosial, ikatan sosial sebagai suatu kelompok tercermin dalam berbagai aktivitas sosial demi mendukung kelancaran ritual hajatan maupun pertunjukan Jonggan.

Jauh sebelum pertunjukan Jonggan dimulai, di ruang dapur telah dimulai aktivitas menyiapkan sajian makanan yang akan dihidangkan dalam perhelatan. Beberapa kelompok perempuan menyiapkan bahan-bahan buah dan sayur untuk dimasak. Bahkan beberapa kelompok lakilaki memotong babi dan memasaknya. Ini merupakan integrasi yang menggambarkan secara jelas kerjasama dalam mewujudkan hajat yang diinginkan.

Pada waktu yang bersamaan di halaman depan rumah beberapa lelaki dengan sigap menyiapkan panggung pertunjukan Jonggan, memasang beberapa lampu untuk menerangi ruang pentas, memberikan beberapa dekorasi sederhana untuk menyemarakkan panggung. Beberapa perempuan dan laki-laki bekerja di ruang tengah rumah. Mereka mengatur meja dan kursi untuk tempat jamuan makan, menata kursi tempat duduk pengantin dengan dekor yang relatif bagus. 
Aktivitas yang dilakukan serempak memperlihatkan aspek kerukunan yang didorong oleh rasa kebersamaan. Pada sekitar panggung pertunjukan beberapa warga mendirikan tenda dan menata beberapa meja mirip ruangan sebuah warung. Beberapa di antara mereka telah mengusung barang dan bahan yang akan diperjualbelikan. Makanan, minuman, dan rokok merupakan jenis yang biasa dipajang di meja warung. Penjual bakso maupun beberapa bentuk perjudian rakyat, semacam permainan dadu, pelakunya nampak mempersiapkan ruang dan peralatan mereka. Ruang ini merupakan ruang publik yang menggambarkan integrasi sosial yang dibangun oleh berbagai peran dan status sosial. Ini juga merupakan media integrasi dari berbagai kepentingan yang sangat memungkinkan ruang ini menjadi ruang pertukaran informasi, barang, uang, dan jasa.

Ruang pertunjukan dalam konteks sosial membangun tatanan ruang yang menggambarkan aktivitas yang bersebaran dalam klasifikasi zona yang secara garis besar dapat dibagi ke dalam tiga zona, yaitu zona inti, zona dukung, dan zona alam. 'Zona inti' terbangun oleh aktivitas ritual dan ruang estetika yang terdiri atas aktivitas ruang pajang manten, upacara ritual, dan aktivitas pentas, yang merupakan aktivitas inti yang menjadi pusat perhatian sekaligus sebagai pusat integrasi sosialnya. 'Zona dukung' merupakan ruang yang dibangun oleh aktivitas sosial yang hadir dalam berbagai peran dan status sosial. Area ketiga merupakan 'zona alam' yang merupakan zona yang memangku peristiwa sosial dan seni pertunjukan, yang dibangun oleh kebudayaan dan lingkungan alamnya.

Pada zona inti terdapat dua peristiwa penting yaitu peristiwa pemeriahan ritual perkawinan dan peristiwa pertunjukan. Dalam ritual perkawinan dapat diamati peristiwa kehadiran warga untuk menyampaikan ucapan selamat, menyampaikan hadiah, dan juga sumbangan sebagai bentuk refleksi toleransi dan kompensasi sosial yang dibangun melalui konvensi nilai kemasyarakatan. Pada peristiwa pertunjukan dapat diamati komunikasi berbagai peran dalam konteks pertunjukan-pengibing, penari Jonggan, pemain musik, penonton secara serempak hadir dengan kekayaan emosinya. Ini merupakan interaksi yang bersifat alamiah sebagaimana dituliskan oleh Basrowi sebagai berikut:

Interaksi yang terjadi secara alami antar
manusia dalam masyarakat yang men-
cakup hubungan antar individu dan
masyarakat. Interaksi antar individu
berkembang melalui symbol yang dicipta-
kan, realitas sosial merupakan rangkaian
peristiwa interaksi simbolis antar individu.
Secara sadar individu menggunakan
bahasa tubuh, gerak, vocal, dan semua
aspek yang mengekspresikan dirinya
sebagai pernyataan simbolisnya (2004: 95).

Partispasi masyarakat dalam lingkungan pertunjukan Jonggan dalam peristiwa pertunjukan dilandasi oleh semangat kolektif warga suku Dayak Kanayatn, kehadiran mereka sebagai pemain ataupun pengibing menjadikan pertunjukannya semarak. Estetika kolektif yang dibangun oleh sense of community memiliki pengaruh terhadap bentuk dan nilai pertunjukan, konvensi bentuk, pola penggarapan medium, perilaku estetik dalam pertunjukan, yang merupakan refleksi budaya indigenious. Integritas sosial warga suku Dayak Kanayatn yang hadir dalam komunitas seni Jonggan mendorong terbangunnya kembali sistem nilai lama dalam tatanan budaya asli. Romantika etnik yang natural dan kemapanan kenyamanan sosial damai mendasari suburnya estetika kolektif 
Jonggan yang divariasikan dengan lagulagu dangdut, menjadikan fasilitas sosial yang terwujud menjamin kehadiran partisipasi warga suku Dayak Kanayatn dalam aktivitas pertunjukan Jonggan.

Menurut penuturan Maniamas Miden Sood (Mantan Timanggong Temila Hilir III), sekitar tahun 50-an ketika Camat Impan memimpin Kecamatan Sengah Temila Pahauman Kab. Landak (Kab. Pontianak kala itu), lagu We' Jonggan memang sudah ada, entah diciptakankan oleh siapa tapi yang jelas lagu itu biasanya dinyanyikan oleh seorang "Pamaliatn/Dukun" ketika mengobati orang yang sedang sakit. Kemudian muncul lagu-lagu lainnya seperti: Dayakng Male'en, Dayakng Aanden, We Aanggon, We Jade, Dayakng Jambelan, dan lain-lain. Waktu pun terus berlalu tanpa disadari lagu-lagu tersebut semakin banyak dipopulerkan oleh kelompok-kelompok Jonggan lainnya.

Masyarakat adat suku Dayak Kanayatn yang tidak tercerabut akar budayanya kesenian tradisional Jonggan sejatinya diselenggarakan sekitar penghujung April sampai dengan awal Mei tahun berjalan, sebagai bentuk ungkapan rasa syukur kepada NekJubata (Sang Pencipta) atas hasil yang telah diterima seorang petani yang mendapatkan padi yang berlimpah.

Seiring dengan berjalannya waktu tradisi ini juga dilaksanakan bagi masyarakat suku Dayak Kanayatn yang tergolong mampu melaksanakan hajatan sunatan atau babalak. Melihat perkembangan Jonggan yang begitu pesat, muncul keinginan Camat Impan untuk melestarikan kesenian tradisional Jonggan sebagai sarana gotong royong, tujuannya agar memudahkan masyarakat di kampung memasarkan hasilhasil pertanian maupun hutan ke Pasar Pahauman kala itu. Wujudnya masyarakat diminta membangun jalan dari kampung ke kampung yang terisolir. Malam harinya masyarakat dihibur oleh kelompok Jonggan yang diselenggarakan oleh Camat Impan secara gratis untuk melepas lelah dan kepenatan setelah siang harinya mereka bergotong royong.

Peristiwa aktivitas keseharian (daily activity), latihan, maupun pentas yang berkaitan erat dengan kesenian Jonggan menjadi lembaga yang menampung aktivitas estetik. Kesinambungan dan keserempakan perjumpaan-perjumpaan mengubah aktivitas kesenian menjadi gerakan sosial yang mengukuhkan nilai estetik yang berakar pada kolektivitas, solidaritas, dan integritas. Dalam konteks peristiwa estetiknya dapat disebutkan tiga nilai estetik yang terbentuk oleh interaksi sosial warga Dayak Kanayatn dalam pertunjukan Jonggan.

Pemeriahan merupakan suasana nyaman, senang, suatu atmosir pertunjukan yang dibangun oleh kehadiran dan partisipasi aktif pelaku pertunjukan. Kemeriahan juga dipahami sebagai gambaran situasi emosional ramai tetapi teduh yang dibangun keteraturan peran, aktivitas yang didasarkan pada sikap saling menjaga, menghormati, dalam berkomunikasi untuk menciptakan suasana nyaman, enak, dan dinamis dalam pertunjukan.

Atmosfir kemeriahan berkaitan erat dengan nilai dan semangat guyub rukun, dari kolektivitas, solidaritas, dan integritas membangun rasa nyaman, enak, dan senang. Interaksi sosial yang dinamis terkendali yang dijalin lewat keserempakan warga suku Dayak Kanayatn dalam menyelenggarakan aktivitas sosial dan estetik, menjadikan sense of community terlihat semakin menguat.

Kemeriahan secara umum diukur lewat kehadiran peran-peran sosial dengan partisipasi sosial yang dibangun lewat 
interaksi dinamis. Kemeriahan dapat diartikan sebagai manifestasi kepekatan interaksi sosial berbagai peran sosial dalam membangun situasi emosional kolektif dalam realitas pertunjukan. Semakin banyak yang hadir dan berpartisipasi dalam realitas pertunjukan suasana kemeriahan semakin menguat.

Kemeriahan dalam penuturan warga suku Dayak Kanayatn juga dipahami sebagai kapasitas partisipasi aktif dalam membangun suasana emosional, terungkap lewat kehadiran warga suku Dayak Kanayatn sebagai pengibing Jonggan atau penonton biasa. Kehadiran warga dalam keserempakan merupakan partisipasi dalam realitas peristiwa pertunjukan, warga suku Dayak Kanayatn yang hadir menyaksikan latihan sambil berbincangbincang tentang banyak hal, peristiwa interaksi sosial di luar konteks estetik membangun suasana kemeriahan yaitu suasana yang melingkupi pertunjukan sebagai fokus aktivitas.

Dalam konteks pertunjukan kemeriahan pada dasarnya tidak memiliki kaitan langsung dengan ekspresi estetik secara langsung, tetapi lebih pada gambaran situasi sosial yang hidup dalam realitas pertunjukan. Ikatan emosional yang dibangun oleh kolektivitas, solidaritas, dan integritas warga suku Dayak Kanayatn dikukuhkan oleh memori kultural yang digali lewat ekspresi estetik. Dalam penuturan kehidupan suku Dayak Kanayatn pertunjukan Jonggan maupun bentuk permainannya dimaknai sebagai sarana hiburan yang sesuai dengan cita rasa, dan selera estetik yang dibentuk indigenious culture.

Kesetaraan dan keserempakan partisipasi sosial setiap peran sosial yang hadir dalam realitas pertunjukan menumbuhkan rasa senang, tenang, aman dan nyaman dalam setiap benak warga Dayak, perasaan dalam budaya selingkung memberikan peluang besar bagi terbangunnya kualitas estetik dalam pertunjukan Jonggan. Kemeriahan dalam realitas peristiwa pertunjukan berpengaruh dalam komunikasi esetetik para pelaku pertunjukan maupun komponen pertunjukan yang lain.

Interaksi dibangun atas dasar tujuan estetik, yaitu pemuasan perasaan estetik untuk menikmati pertunjukan musik, menikmati tarian, permainan gamelan, nyanyian sindhen, maupun melampiaskan hasrat mengekpresikan diri dengan menari, menyanyikan lagu maupun bersenda gurau. Dinamika pertunjukan yang dibangun oleh peristiwa permainan pemain Jonggan gerakan tubuh yang memabukkan pemain, serta pantun dan syair yang dilantunkan.

Dalam aktivitas pertunjukan Jonggan aktivitas pertunjukan berakar pada bentuk lantunan lagu, alunan musik, dan aktivitas estetik pelaku pertunjukan Jonggan. Bentuk pertunjukan Jonggan dalam konteks pemenuhan kebutuhan estetik terkandung dalam struktur pertunjukan. Bagian awal yang mencerminkan estetika formal ini merupakan bagian yang memberikan kesenangan visual auditif dengan polapola yang baku, dan terstruktur. Bagian kedua merupakan pemuasan estetik yang bergayut pada estetika pemuasan emosional dengan pola-pola garap medium yang diakrabi dalam tradisi Jonggan.

Hal ini memudahkan serta mengukuhkan integrasi sosial di kalangan warga suku Dayak Kanayatn dalam pemikiran yang mendasar. Aktivitas tersebut menumbuhkan keteraturan behaviouriostik yang berkaitan erat dengan gerak sosial masyarakat. Sebagaimana dikatakan oleh Basrowi pada prinsipnya dalam kehidupan manusia ada tiga bentuk aturan yang mengatur 
perilaku manusia dalam berintreraksi sosial yaitu: aturan mengenai ruang, aturan mengenai waktu, sikap dan gerak tubuh (2004: 99).

\section{Hightech dan Alih Media: Konvensi, Kreasi, dan Promosi}

Tatanan sosial masyarakat dengan perubahan yang dituntun oleh hightech, tradisi budaya etnik suku Dayak Kanayatn akhirnya mengadopsi berbagai strategi melalui proses alih media, pengayaan media. Tantangan komunikasi global menuntun tradisi budaya etnik suku Dayak Kanayatn merasuki media tayang sebagai wahana aktualisasi diri. Dengan demikian resistensi nilai dan bentuk budaya etnik suku Dayak Kanayatn semakin kuat baik dari sisi filosofis maupun tantangan ekonomi. Kepentingan pembentukan karakter dan pekerti bangsa, identitas, bereksistensi dengan kepentingan pengembangan eko-nomi. Komodifikasi budaya etnik suku Dayak Kanayatn akan mewarnai fenomena tradisi budaya etnik Dayak yang dituturkan sebagai tradisi pertunjukan yang dipenga-ruhi faktor, sosial politik, ekonomi, dan budaya.

Hal ini merangsang tumbuhnya perubahan bentuk estetik, cita rasa, moral, dan etika. Perubahan dapat diamati pada tradisi pertunjukan yang mulai memba-ngun integritas melalui proses alih media dari pertunjukan menuju penggarapan medium seni pertunjukan. Hal ini men-jadikan posisi budaya etnik suku Dayak Kanayatn yang dituturkan sebagai tradisi pertunjukan dapat hidup pada berbagai ruang publik, yaitu: (1) ditengah budaya masyarakat agraris yang alami dan (2) berkembang ke arah media rekam dan tayang.

Memasuki periode reformasi, ketika negara sedang dilanda krisis moneter, beberapa seni pertunjukan tetap bertahan hidup dengan caranya sendiri. Proses kreatif dan aktivitas mereka dikendalikan oleh spirit religi sembari mengeksplorasi fungsi ekonomi kesenian yang ditekuni. Proses kreatif kelompok seni pertunjukan rakyat cenderung responsif terhadap bentuk-bentuk penawaran yang "laku" untuk dijual dan mudah dijumpai dalam realitas lingkungan.

Dengan demikian seniman sebagai pelaku seni harus secara sadar memainkan dua wajah untuk menyeimbangkan nilai filosofis dengan tumbuhnya nilai ekonomi pada sastra dan tradisi pertunjukan yang tumbuh dan berkembang dalam kehidupan masyarakat. Hampir tiap kelompok meresitasi identitas kedaerahan dalam media seni pertunjukan. Alih media ini memberikan gairah perkembangan komersial pada pelaku seni pertunjukan.

Pertumbuhan ekonomi kreatif telah digerakkan generasi muda dan media massa mampu melahirkan karya-karya yang laku dan layak jual seperti iklan, desain, permainan interaktif, seni pertunjukan, film, animasi, fashion, musik, software, game komputer, dan sebagainya. Perkembangan ekonomi kreatif ditopang industri kreatif, berakar pada pemanfaatan kreativitas, keterampilan serta bakat individu dalam menciptakan peluang kerja.

Intervensi market oriented dalam penggarapan estetika semakin kuat. Aneka ragam modifikasi bentuk gendhing secara dominan dengan berbagai gaya dan cita rasa. Gubahan dan modifikasi tersebut didasarkan pada perkembangan bentuk-bentuk seni pop yang sedang laku di pasaran sehingga untuk produk rekaman VCD cenderung menyajikan lagu dan gendhing yang sedang populer. Pelaku seni bangga pementasannya direkam seorang produser VCD lokal, karena mendapat tambahan honor serta dapat merintis popularitas lewat VCD yang akan beredar di pasaran 
Estetika lingkungan yang bersifat trend, populer, lugas, dan sederhana membuat penawaran seni pertunjukan selalu diterima lingkungan. Perkembangan estetika syair-syair yang digarap lebih berorientasi pada selera pasar melahirkan kemasan bernuansa pop, kekinian yang lebih bersifat konsumtif dan instan. Bentuk perubahan tersebut dapat diamati melalui peredaran kaset Jonggan dari berbagai gaya, dan corak kedaerahan. Tradisi pertunjukan Jonggan maupun tradisi yang lain dalam budaya adati yang dialihmediakan pada akhirnya juga merebak dalam kemasan DVD dan VCD.

Merebaknya media hiburan elektronik VCD/DVD player yang harganya terjangkau oleh berbagai kelas masyarakat, mendorong tumbuhnya usaha lokal memproduksi kaset VCD dari berbagai sumber seni hiburan. Seni pertunjukan menjadi aset pengembangan ruang komersial. Beredarnya keping VCD merangsang popularitas pelaku seni pertunjukan. Penari, repertoar tari, maupun media pencangihnya dieksploitasi guna memenuhi kepentingan komersial. Komodifikasi tubuh, komodifikasi penampilan, komodifikasi kegairahan diarahkan pada kepentingan profit, media teknologi canggihnya menghasilkan efek pelipatgandaan, intensifikasi energi libido, reorientasi dan modifikasi arus hawa nafsu (Piliang,1998: 96).

Beralihnya penuturan tradisi pertunjukan pada media tayang mengubah bahasa dan ungkapan sastra dan seni pertunjukan menyesuaikan tantangan pasar yang cenderung mengindahkan kaidah seni massa. Terjadi perubahan bahasa tubuh, bahasa, dan tatanan estetiknya. Bahasa cenderung tidak menggunakan bahasa lokal, lebih mencerminkan hibridasi dalam berbagai penggarapan mediumnya. Ini dapat diamati pada berbagai produk VCD dan DVD yang mengaktualkan tradisi pertunjukan suku Dayak Kanayatn dll.

\section{SIMPULAN}

Kesenian Jonggan dalam kehidupan warga suku Dayak Kanayatn memiliki fungsi kultural mencakup aktualisasi nilai-nilai kultural yang berkaitan erat dengan nilai kehidupan sosial, nilai estetik kesenian yang dihayati sebagai ekspresi komunal dan individu, serta pencapaian kearifan hidup yang berakar pada kearifan kultural. Pertunjukan Jonggan dalam lingkup budaya adat Dayak Kanayatn merupakan aktivitas sosial budaya yang berkaitan erat dengan tujuan-tujuan sosial, sementara sebagai peristiwa seni dapat dimaknai sebagai peristiwa estetik dan peristiwa sosial budaya.

Melihat perkembangan jaman kesenian Jonggan dihadapkan pada perubahan tatanan budaya sosial ekonomi bersifat global. Tumbuh peluang mengembangkan kesenian sebagai aset ekonomi politik dan integritas budaya di tengah tantangan budaya global. Tumbuhnya hightech merangsang tumbuhnya ekonomi kreatif yang mendorong tumbuhnya komodifikasi terhadap kesenian Jonggan.

\section{Daftar Pustaka}

Billa, Marthin

2005 Alam Lestari dan Kearifan Lokal Budaya Dayak Kenyah. Jakarta: Pustaka Sinar Harapan.

Hauser, Arnold

1978 The Sosciology of Art. Chicago: The University of Chicago Press.

Heddy Shri Ahimsa-Putra.

2003 "Ethnoart Fenomenologi Seni Untuk Indiginasi Seni" dalam Dewa Ruci. Vol. 1, No. 3 : 343-367.

\section{Hermansyah}

2010 Ilmu Gaib di Kalimantan. Jakarta: KPG Kepustakaan Populer Gramedia. 
Maniamas Miden S.

1999 Dayak Bukit: Tuhan, Manusia, Budaya. Pontianak: Institut Dayakologi.

Mudji Sutrisno

1993 Nuansa-nuasa peradaban. Yogyakarta: yayasan kanisius.

Muhamad Basrowi

2004 Teori Sosial dalam Tiga Paradigma. Surabaya: Yayasan Kampus Surabaya.

Nico Andasputra Stepanus Djuweng (ed). 2010 Manusia Dayak: Orang Kecil Yang Terperangkap Modernisasi. Pontianak: Institut Dayakologi.

Niko Andaspura, Vincentius Julipin (Ed). 2011 Mencermati Dayak Kanayatn. Pontianak: Institut Dayakologi.

Paulus Florus, dkk (Ed).

2010 Kebudayaan Dayak: Aktualisasi dan Transformasi. Pontianak: Institut Dayakologi.

Royce, Anya Peterson

2007 Antropologi Tari. Terjemahan dari The Anthropology of Dance oleh: F.X Widaryanto. Bandung: Sunan Ambu Press.
Shils, Edward.

1981 Tradition. Chicago: The University of Chicago Pers.

Stepanus Djuweng, dkk (Ed).

2003 Tradisi Lisan Dayak:Yang Tergusur dan Terlupakan. Pontianak: Institut Dayakologi.

Storey J.

2003 Teori Budaya dan Budaya Pop: Memetakan Lanskap Konseptual Cultural Studies.

Veth, P.J. Yogyakarta: Qalam.

2012 Borneo Bagian Barat:Geografis, Statistik, Historis. Alih Bahasa: P. Yeri, OFM. Cap. Pontianak: Institut Dayakolog.

Yasraf Amir Piliang

1998 Sebuah Dunia yang Dilipat: Realitas Kebudayaan Menjelang Millenium Ketiga dan Matinya Posmodernisme. Bandung: Mizan.

1999 Hiperrealitas Kebudayaan. Yogyakarta: LKiS.

\section{Sumber lain}

Wawancara dengan Bihen, 5 Pebruari 2009) 